\title{
Poder real, autoridade do clã e o governo de Javé
}

\author{
Royal power, clan authority, and Yahweh's governance
}

\section{Erhard Siegfried Gerstenberger}

Doutor em Teologia pela Philipps Universität Marburg, Alemanha, e-mail: gersterh@staff.uni-marburg.de

\section{Resumo}

0 artigo propõe investigar novamente algumas questões limitadas da organização social do antigo povo de Israel em relação à práxis política do poder e suas consequências para a vida espiritual e ética. Reflete ainda a respeito dos motivos de elogiar a instituição do reinado israelita em algumas camadas literárias e de denunciá-lo severamente em outras, bem como reflete também sobre o fenômeno concomitante de desprezar ou glorificar as chefias tribais. A autoridade familiar, sendo o modelo primeval de organização social, também tem um papel importante nessas considerações. Todas as opiniões encontradas nas Escrituras a respeito de qualquer organização certa e humana são motivadas por argumentos religiosos: sempre é Deus que ordena e patrocina as estruturas sociais. Assim, a pluralidade das concepções legítimas revela teologias diferentes, seja em tempos sucessivos seja ancoradas em classes precariamente coexistentes.

Palavras-chave: Família. Poder. Monarquia. Antigo Israel. Organização social. 


\section{Abstract}

This article proposes to investigate again some limited issues of social organization of the ancient people of Israel in relation to the practice of power politics and its consequences for the spiritual life and ethics. It also reflects about the reasons to praise Israel's monarchy on the one hand and castigate it severely on the other, as well as on the phenomenon of concomitant neglect or glorification of the tribal leadership. Family authority, being the arch model of social organization, also has an important role in these considerations. All opinions we may find in the Scriptures in regard to just and humane structures of society are motivated by religious arguments. It is always the ordinance of a Deity which institutes legitimate governance. In this fashion, the plurality of opinions reveals the diversity of theological concepts which either follow each other successively or are present in precariously coexisting social classes.

Keywords: Family. Power. Monarchy. Ancient Israel. Social organization.

\section{Introdução}

A interpretação das Escrituras (mas também de outros documentos da fé e da literatura geral) sempre precisa, novamente, de reflexões e verificações metodológicas e hermenêuticas para encontrarmos os acessos mais oportunos ao texto antigo, a saber, às suas concepções, afirmações, opiniões, confissões de fé, etc. Proponho aqui investigar novamente algumas questões limitadas da organização social do antigo povo de Israel em relação à práxis política do poder e as suas consequências para a vida espiritual e ética. Há, especificamente, tradições bastante divergentes no Antigo Testamento em relação à pergunta bem fundamental em toda história humana: qual seria o governo legítimo e agradável à Divindade venerada? Tal questão, naturalmente, também implica a utilidade e a justiça da liderança para os liderados. Mais precisamente, quero refletir sobre os motivos de elogiar a instituição ou administração do reinado em Israel por um lado e de denunciá-lo severamente por outro, bem como refletir, também, sobre o fenômeno concomitante de desprezar ou glorificar as 
chefias tribais. A autoridade familial também faz papel importante nessas considerações. Onde residem as raízes de tais perspectivas divergentes? Baseando-me em estudos anteriores (GERSTENBERGER, 2001; 2007), pretendo apontar vários pontos de vista, vinculados com condições sociais dos respectivos autores e transmissores dentro do Antigo Testamento, que miram as lideranças políticas do próprio povo de Israel de ângulos bem diferentes. Com isso, gostaria de destacar a importância enorme da organização social que, na última análise, afeta até as concepções e articulações da fé. "O Verbo universal só fala em dialeto" diz Pedro Casaldáliga (1979, p. 45). E o apóstolo Paulo concorda: "agora vemos em espelho e de maneira confusa" (1Cor 13,12).

\section{Antigo Testamento e organização social}

Vale destacar, desde o início, que a redação final dos escritos hebraicos deixa completamente aberta a questão de uma ordem divina e normativa, seja para a humanidade toda seja para o povo de Israel em particular. Há, isso sim, camadas distintas, como a sacerdotal, que favorecem certa organização teocrática da comunidade. Mas, ao deixar entrar na coletânea dos livros sagrados opiniões teológicas tão variadas, os responsáveis obviamente querem sugerir a imperfeição de qualquer ordem social no mundo humano. Não há, no cânon veterotestamentário, organização ideal, mas uma sensibilidade aguda para variações e desenvolvimentos sociais ao longo dos tempos, bem como para a ambivalência de todas as estruturas possíveis. Da mesma forma, existe no Antigo Testamento uma consciência marcante de que cada organização social, da menor até a maior, implica fatores de poder e da autoridade. ${ }^{1}$ Com isso não quero ignorar, de jeito nenhum, que determinados autores e grupos identificáveis dentro

1 A literatura sociológica que se dedica a esse fenômeno é rica, cf. apenas as obras clássicas de Max Weber (por exemplo: Das antike Judentum. Gesammelte Aufsätze zur Religionssoziologie III, 1921. 8. ed. Tübingen: Mohr 1988) e Karl Mannheim (Mensch und Gesellschaft im Zeitalter des Umbaus. Leiden: Sijthoff, 1935), depois de numerosos estudos maxistas, começando com Karl Marx (cf. Manifest der kommunistischen Partei 1848. In: LANDSHUT, S., MARX, K. Die Frühschriften. Stuttgart: Alfred Kröner, 1953. p. 525-560). Cf. também o estudo famoso de Hannah Arendt: ARENDT, H. Macht und Gewalt (1970). 17. ed. München: Piper 2006. 
de algumas tradições bíblicas defendam uma única opção política, como, por exemplo, a monarquia (cf. 2Sm 7; Sl 45; 89; 110). ${ }^{2}$

Podemos verificar algumas concepções e preocupações dos nossos antepassados bíblicos já, por exemplo, na "introdução à história humana" (história primordial) em Gn 1-11. Esse bloco de material narrativo e poético contém uma boa porção de motivos e conceitos diferentes em torno da criação e finalidade da humanidade. Começa, na parte mais antiga ( $\mathrm{Gn}$ 2-5), com um casal que se multiplica rapidamente. Assim, visa, desde o início, à humanidade plena como alvo da atuação divina (Gn 6-11). Depois, a concepção pura e teoricamente universal se propõe a essa linha de pensar (Gn 1-2:4a). Dessa forma, encontramos interesse forte dos nossos pais espirituais em uma história humana globalizante. Essa história, no entanto, tem as suas raízes em grupos humanos íntimos, na relação entre homem e mulher (cf. Gn 3) e irmãos (Gn 4,1-8), dependendo, na última análise, do comportamento individual e familiar ( $\mathrm{Gn}$ 6,9-22). Existe essa grande tensão, em todas as Escrituras, entre a vida organizada em pequenas unidades de parentesco e as organizações secundárias de maior porte, ${ }^{3}$ sejam elas clãs, tribos, vilas, cidades ou, idealmente, a humanidade completa. Já em Gn 4,17-22 se imagina nitidamente o processo cultural "civilizatório" (RIBEIRO, 1979). Entendemos, portanto, que os teólogos do AT eram plenamente conscientes das diversas formas da vida social, dos problemas de organização e da autoridade inerentes.

\section{Poder familiar}

A raiz milenar pré-histórica da autoridade patriarcal reside na estrutura da família no âmbito das culturas do antigo Oriente Médio, acima de

2 Cf. também a ideologia real nas culturas do antigo Oriente Médio como patente em inúmeros documentos reais desde o terceiro milênio a.C. Nas antigas “listas dinásticas", o reinado vem do céu, como uma dádiva divina, dividindo a história universal em dois períodos: a época pré-real e aquela civilizada por meio da monarquia, cf. JACOBSEN T. The Sumerian King List. Chicago: University Press, 1939; WILCKE, C. Die Sumerische Königsliste und erzählte Vergangenheit. In: UNGERN-STERNBERG J. von et al. (Ed.). Vergangenheit in mündlicher Überlieferung. Stuttgart: Teubner, 1988. p. 113-140.

3 Cf. KESSLER, 2006, p. 49-72.

Rev. Pistis Prax., Teol. Pastor., Curitiba, v. 3, n. 1, p. 77-98, jan./jun. 2011 
tudo na divisão do trabalho conforme as linhas de gênero. Houve aquela bem conhecida e arcaica partição em áreas de dentro e de fora da casa familiar. O campo doméstico estava sob controle da mulher ou das mulheres, enquanto qualquer empenho distante da moradia para sustentar o pequeno grupo familiar pertencia ao homem, o membro mais flexível da turma. Enquanto havia certo equilíbrio entre as funções de "proteção, procriação e produção", o sistema durante épocas extensas ofereceu direitos quase iguais aos gêneros (MYERS, 1988). Também reinava certo equilíbrio gradativo quanto à posição de crianças, anciãos, parentes e estrangeiros convivendo em uma família nuclear. Da mesma forma, o estatuto de escravos e escravas sempre dependia do sentimento individual dos patrões e donos. Contudo, no desenvolvimento milenar o líder masculino da organização primária da humanidade ganhava, de modo geral, sempre mais poder em vários campos da vida. Existem indícios no AT de que homem e mulher colaboravam bem, por exemplo, na área da educação dos filhos ( $\operatorname{Pr} 1,8$; 6,20; Dt 21,1821). Ambos os pais ficam sob proteção especial da divindade (Ex 21,15; $\operatorname{Pr}$ $19,26 ; 20,20 ; 28,24 ; 30,11-14.17)$. Mas acontecia que o pai gradativamente tornava-se herdeiro exclusivo das propriedades familiares e chefe da casa chamada por seu nome. A jurisdição interna é um exemplo (castigo até a morte: Prov 19,18; condenação de familiares: Gn 38,24; Lv 21,9); a legislação familiar (Jr 35,6-10) igualmente ficava sob o cuidado do chefe familiar masculino. Por dentro da micro-organização familiar aparentemente havia modalidades bem antigas e estáveis de organizar a vida em conjunto, incluindo os padrões de trabalhar, festejar, educar, resolver conflitos, regular a sexualidade (cf. Lv 18,6-18), defender-se, exercer solidariedade, etc. O poder paternal e maternal e também a autoridade dos filhos mais velhos sobre os menores e a dominação sobre pessoas escravizadas, bem como estrangeiras ou afiliadas à família nuclear, eram definidos sem qualquer escritura e pelos costumes tradicionais. Provérbios e estórias modelo transportavam, oralmente, aquilo que "se tinha que fazer", ou aquele comportamento que "não dava de jeito nenhum". A autoridade patriarcal crescia pelos séculos, mas também era supervisionada pela opinião pública da comunidade como se percebe, por exemplo, em $\operatorname{Pr} 10-31$. O poder sobre menores e inferiores parece ter sido considerado como algo normal. No entanto, abuso de poder, era um crime, já nessa camada mais baixa da sociedade. Desse modo, 
poder e autoridade dependiam, além dos papéis tradicionais, da experiência, know-how, idade, prudência, sinceridade e outras qualidades humanas. Pode-se imaginar que os parâmetros da "hierarquia doméstica" adquiriram funções modelares, arquetípicas para qualquer construção social secundária. Prova disso pode ser o título de "pai" conferido - se não explicitamente ao rei terrestre - à divindade suprema (cf. Isa 63,16; 64,7; Jer 3,4.19; 31,9; Ml 1,6; Ps 68,6; 103,13 e muitas vezes no NT).

Vale destacar justamente aquele ponto anteriormente mencionado, isto é, a sensibilidade fina para a legitimidade e o abuso do poder: a organização social, da base familiar até as cúpulas mais altas de reinados e impérios, conforme o AT, é uma necessidade intrínseca. Os homens, criados macho e fêmea, de qualquer maneira precisam de orientação e liderança, especialmente na juventude. Mas, infelizmente, o abuso de poder e autoridade sempre estão próximos. O veredicto sobre a mulher reza: "teu desejo te levará ao teu marido e ele te dominará" $(\mathrm{Gn} 3,16)$. Parece que até o raciocínio machista nesse ponto deixa transparecer certa pena com a subjugação costumeira da mulher. Implicitamente, se reconhece a precariedade de qualquer exercício de poder de um sobre o outro (cf. Lv 25,43: "não o dominarás com tirania"; Pr 28,16: "um príncipe sem inteligência multiplica as extorsões"; Ez 28:2 (sentença contra o rei de Tiro): "pois que o teu coração se exalta orgulhosamente e dizes: 'Eu sou Deus'”, e muitos outros exemplos). Isso significa: a organização social implicando o exercício de poderes de coerção torna-se, nas Escrituras do AT, um problema estritamente teológico. Deus, no fundo, não quer nem uma subjugação total nem uma exploração indigna de ninguém (apesar de não colocar em dúvida as instituições patriarcais de matrimônio ou da escravidão). Quer, na verdade, uma vida digna para os seus adeptos e, num sentido maior, de toda a humanidade (cf. acima de toda a legislação social para o Antigo Israel em Ex 21-23; Dt 22-25; Lv 19).

\section{Tribalismo $=$ desordem $\times$ monarquia $=$ salvação}

Por causa da falta de recursos originais e da incerteza geral sobre a datação daqueles textos que efetivamente falam do sistema tribal em Israel 
e da transição para a monarquia emergente, realmente fica difícil elaborar as opiniões antigas sobre o assunto. ${ }^{4}$ Mesmo assim, existem indícios que podemos utilizar. Existe o termo técnico de "tribo" na antropologia social e na sociologia e, pelo menos na perspectiva posterior dos transmissores do material veterotestamentário, Israel uma vez foi organizado em tribos. Lidamos, então, sem sobrecarregarmos esse conceito, com os testemunhos que temos no AT, principalmente nos livros dos Juízes e de Samuel e no primeiro livro dos Reis. Neles podemos descobrir traços, aqui e ali, de uma estimação bem alta da monarquia. Ela se tornou necessária por causa da falta de eficácia do sistema anterior, a saber, em manter a segurança externa (cf. 1 Sam 11), ${ }^{5}$ bem como a ordem interna (cf. Jz 17,6; 18,$1 ; 19,1 ; 21,25$ = comentário tardio sobre Jz 17-21). Os dois argumentos parecem plausíveis para nós. Especialistas da história antiga de modo geral os aceitam como historicamente prováveis. Os redatores da tradição israelita, porém, não se preocupavam tanto com a probabilidade histórica, mas julgavam assuntos desse porte teologicamente. Por que alguns deles (sem definirmos a época ainda de tal parecer) viram a entronização de um rei legítimo em Israel sob os olhos de Javé?

Os relatos positivos da entronização de um rei nem tocam na legitimidade dessa inovação constitucional. Temos que procurar outras informações sobre a essência da monarquia israelita para entendermos tal mudança profunda na organização social. Existem textos significativos no AT que falam da sacralidade (ou santidade!) do rei; fazem isso sem qualquer constrangimento (cf. Salmos 2; 20; 45; 89; 110; 2Sm 7,4-16; 23,2-7, etc.). No entanto, essa apreciação de que o rei serviu como mediador das graças divinas para o seu povo já era um conceito comum no antigo Oriente Médio, mais do que dois mil anos antes da chegada de Israel no palco da

4 Houve uma época na qual se falava pacificamente sobre "as tribos", até mesmo de um "sistema tribal" do povo de Javé que antecedeu a monarquia de Saul, Davi e Salomão, cf. p.ex. as obras relevantes de Martin Noth ou Norman Gottwald. Por outro lado, Rainer Kessler hoje em dia nem quer mais empregar tecnicamente essa palavra, cf. Kessler (2006, p. 59, n. 81), prefere a expressão "verwandtschaftsbasierte Gesellschaft" (sociedade baseada em relações de parentesco (2006, p. 49).

5 Os episódios de Jz 9,1-6 e Jz 11,1-11 (falta ainda o título "rei" para Jefta) na verdade refletem situações semelhantes. 
história. ${ }^{6}$ Outros líderes designados por Javé incluíram naquela época o "juiz" (šopeț) e o "guerreiro ungido" (nazîr) como apresentados bem positivamente no livro dos Juízes (mais Saul que recebeu também o "espírito estático de Deus", 1Sm 10; cf. Sansão em Jz 13-16; Nm 6). Na verdade, os dois tipos de liderança (rei versus escolhidos) dependiam da escolha e benção pelo próprio Deus, mas existiam grandes diferenças entre eles, as maiores sendo a instituição firme e dinástica do reinado, o maior poder acumulando-se quase que automaticamente sobre uma cabeça coroada. Tipicamente, os líderes mais próximos de uma autoridade real no livro dos Juízes, a saber, Gedeão, Abimelec e Jefté, recrutam, com a aprovação de Deus e do povo, mercenários para formar um exército particular e quase real ( Jz 9,4; 11,3; [7,1-8]). Se, agora, a instalação de um novo rei fica narrada sem dúvida alguma, temos que postular uma estimação forte do candidato e da instituição. Provavelmente isso aconteceu nos moldes do antigo Oriente Médio, estabelecendo-se o costumeiro mediador das forças divinas. "Tu és meu filho" (S1 2,7) e "senta-te à minha direita" (S1 110,1) são oráculos de Javé ao rei entronizado; "teu trono, ó ser divino, fique para sempre" (Sl 45,7), entoa a comunidade de fiéis. Sentimentos como esses devem ter estado atrás do movimento israelita que elevava e apoiava líderes dinásticos no Antigo Israel, mesmo considerando possíveis misturas de conceitos monárquicos e carismáticos (cf. 1Sm 10; a dádiva do espírito divino com expressões extáticas concorda mais com uma estrutura tribal, não cabe ao rei; 2Sm 6,2022). Essa visão bem positiva do rei se faz presente com elogios profusos da sabedoria divina de Salomão (cf. 1Rs 3), da sua imensa riqueza e extensão de poder (1Rs 11; Sl 21). O rei é mediador das bênçãos divinas, ele garante justiça e ordem, dominação sobre povos vizinhos e até chuvas suficientes e fertilidade do solo (cf. Sl 72). Na luz dessas expectativas gerais diante da instituição real dinástica generalizada no Antigo Oriente Médio, é claro que a estrutura tribal, ou seminômade, torna-se um símbolo de regressão, barbaridade, de cunho anticivilizatório. $\mathrm{Na}$ época das tribos reinava o caos, rezam os redatores do livro dos Juízes, "cada qual fazia o que bem lhe parecia"

6 Cf. AHN, G. Religiöse Herrscherlegitimation im achämenidischen Iran. Acta Iranica, 31, Leiden und Louvain, 1992; FRANKE, S. Königsinschriften und Königsideologie. Die Könige von Akkade zwischen Tradition und Neuerung (Altorientalistik 1). Münster: LIT-Verlag, 1995; GERSTENBERGEr, E. S. Königskritik. Disponível em: $<$ www.wibilex.de $>$.

Rev. Pistis Prax., Teol. Pastor., Curitiba, v. 3, n. 1, p. 77-98, jan./jun. 2011 
(Jz 17,6; 21,25). Faltava o saber, a sabedoria e, acima de tudo, a inspiração calma e contínua divina que só um monarca podia providenciar.

\section{Monarquia $=$ soberba $\times$ tribalismo $=$ liberdade}

O prestígio do sistema real, entendido política e ideologicamente, constituía o pano de fundo geral nas culturas do antigo Oriente Médio, das quais o Antigo Israel fazia parte integral em todas as áreas da vida e da fé. ${ }^{7}$ À luz desse fato é imensamente curioso que o AT mostre tantas dúvidas e ressalvas, diante da ordem social dinástica, teologicamente fundadas contra ela, lançando até ataques ferozes. Será que era a organização social diferente do Israel Antigo que produzia tais críticas? O povo de Javé talvez tivesse se ligado mental e teologicamente com a ordem tribal da época pré-estatal? Ou seja, que a profunda aversão contra uma autoridade dinástica nasceu apenas pelo fim da história antiga, isto é, da organização paroquial e eclesial que se formou durante a época pós-exílica? Particularmente prefiro a segunda alternativa, pois acredito que o AT preserva poucas informações da história pré-exílica. Outros especialistas optam por uma origem pré-exílica da linha crítica de pensamento. ${ }^{8}$ Não importa tanto a datação desses posicionamentos negativos. Vale, isso sim, observar alguns argumentos e implicações.

A oposição político-religiosa à monarquia talvez corresponda mais a experiências vivas de abuso de poderes reais. Já no relato extenso sobre a lendária época do governo de Davi e os problemas de sucessão (2Sm 5-1Rs 2) encontramos muitas críticas ao célebre e exemplar rei, na maioria decorrentes de erros e falhas do governo. Assim, o príncipe herdeiro Absalão agita contra o pai tentando explorar e fomentar a desconfiança dos súditos na justiça governamental (cf. 2Sm 15,1-6). A integridade ética de Davi fica subvertida por contos como o do seu adultério com Betsabéia (2Sm 11). A maldição do rei, proferida por Semei, um membro do clã do

7 Cf. GERSTENBERGER, Teologias 326-335; idem, Israel 324-328.

8 A literatura que trata desse assunto é vasta, basta fazer referência às obras citadas de Crüsemann, Gottwald e Albertz, 1992. 
antecessor no reinado (2Sm 16,5-14), claramente é designada um ato de vingança pelo narrador. Dado o fato de que o ungido é intocável (cf. 2Sm 24,7.10-11), a ação de Semei parece ser uma monstruosidade. Mesmo assim, ela fica por dentro da caracterização dada de uma "oposição pontual, concreta e política”. O narrador, não importando a época na qual ele articula a sua opinião, parte da realidade do antigo Oriente Médio de todas as épocas. Ansiedades e precauções de revolução, insurreição e vingança constituíam o dia a dia das cabeças coroadas.

Mais interessante para nós é a crítica fundamental da estrutura dinástica que também se encontra no AT, ao menos se aceitarmos alguns textos como tal. ${ }^{9}$ No centro da atenção acadêmica sempre se encontrava a "fábula de Joatão" em Jz 9. O jovem mal sobreviveu a um massacre cometido pelo pretendente a rei Abimelec, que matou todos os seus outros irmãos, filhos de Jerobaal, sendo eles concorrentes perigosos. O lindo poema (v. 7-15) retrata a "sociedade das árvores" querendo ungir um rei sobre elas mesmas. Os representantes mais nobres da grande plantação, oliveira, figueira e videira, quase que em uníssono recusam a oferta de "reinar sobre os outros". O argumento decisivo é, caso aceitassem o posto elevado de governar, que iriam perder as suas raízes, os seus frutos tirados da terra, "balançando sobre as árvores" (v. 9.11.13). O verbo hebreu nua' conota instabilidade, fraqueza, perda de orientação e "talvez implique, neste lugar, uma crítica escondida da monarquia". ${ }^{10}$ No fim, a planta mais inadequada e inútil para executar um governo justo realmente aceita a oferta de ofício, o espinheiro (v. 14-15).

Então todas as árvores disseram ao espinheiro: 'Vem tu, e reina sobre nós!' E o espinheiro respondeu às árvores: 'Se é de boa fé que me ungis para reinar sobre vós, vinde e abrigai-vos à minha sombra. Se não, sairá fogo dos espinheiros e devorará os cedros do Líbano!'

Ironia e sarcasmo permeiam o poema: qualquer ouvinte já na antiguidade deve ter rido em voz alta quando o espinheiro respondeu às árvores:

\footnotetext{
9 Müller (2004) não admite a interpretação sistêmica dessa fábula.

10 RINGGREN, H. ThWAT, v. 5, 316.
} 
"vinde e abrigai-vos à minha sombra" (v. 15). Por outro lado, a sociedade natural e bem mais vantajosa é aquela fortemente enraizada no solo local ou regional, mas não nacional nem real ou imperial. Essa sociedade promove o bem-estar comum, não aquela outra construída pela vontade do rei. Só a antiga tradição deixa crescer as habilidades de qualquer um e de seus diversos frutos. A organização costumeira de pessoas iguais em seus direitos e deveres providencia dignidade e liberdade dos cidadãos, enquanto a monarquia vai destruir as características das pessoas subjugadas. ${ }^{11}$

O julgamento literário do rei Salomão (cf. 1Rs 5,27-32; 9,15-23; $11,28 ; 12,3-14)$ é sucinto e ainda mais escondido; acontece em forma de narração factual. Mas já nessa fase de apresentação os transmissores utilizam parcialmente o vocabulário drástico da escravidão do povo de Israel no Egito (Ex 1-13). ${ }^{12}$ Assim, o recrutamento de trabalhadores para as grandes obras do rei israelita torna-se comparável à opressão feita pelo faraó do Egito. De fato, o próprio Salomão assume o rosto do faraó. Mais tarde, as negociações sobre a continuação da dinastia de Davi em 1Rs 12,1-19 revelam as consequências da extorsão do povo pelo rei: agora o filho de Salomão, prestes a assumir a regência depois da morte do pai, enfrenta a oposição determinada das 10 tribos do norte. Eles constatam e exigem: "teu pai tornou pesado o nosso jugo; agora, alivia a dura servidão de teu pai e o jugo pesado que ele nos impôs e nós te serviremos" (1Rs 12,4). Roboão, o príncipe davídico, rigidamente rejeita qualquer redução das cargas pesadas e até promete um aumento severo delas (v. 10-14). Consequentemente, realiza-se o cisma das tribos de Israel, levando o reinado do norte a implantar as suas próprias estruturas, possivelmente menos hierárquicas do que aquelas de Jerusalém (1Rs 12,20-30). A questão que temos que levantar é: até que ponto a crítica da monarquia dinástica de Judá deixa transparecer um ideal da vida e constituição tribais? O ponto decisivo do debate é o "peso" da administração real em termos de tributo e corveia. Os anciãos de Judá aconselham concessões prudentes para assegurar a lealdade dos sujeitos (1Rs 12,6-7) - certamente tendo

${ }^{11}$ A fábula termina com a ameaça aos dissidentes. Se eles não aceitarem as condições do acordo, então “sairá fogo dos espinheiros e devorará os cedros do Líbano!" (Jz 9,15).

12 Cf. GEORGE V. Pixley, Êxodo. Una lectura evangélica y popular. México: Casa Unida, 1983 (trad. inglês: On Exodus, a Liberation Perspective. Maryknoll: Orbis Books, 1987). 
em vista condições mais livres e menos reguladas de vida, como em organizações tribais.

Os nossos documentos veterotestamentários não oferecem discursos teóricos nem comparações proverbiais ou diálogos competitivos ${ }^{13}$ sobre o valor dos diferentes sistemas sociais. Passagens relevantes nos livros dos Provérbios (p.ex. Pr 25,2-7) e Eclesiastes (p.ex. Ecl 10,16-17.20) consideram a existência do reinado uma realidade pacífica, admitindo somente possíveis aberrações. Da mesma forma, invectivas proféticas via de regra criticam erros concretos cometidos por reis e elites dominantes (cf. Os 8,4; Is 7,3-9; Jr 22,13-19, etc.); ${ }^{14}$ afirmações escatológicas às vezes glorificam de novo o ideal do reinado davídico (cf. Am 9,11-12; Is 9,5-6; 11,1-9; Ez 34,23-24). A parábola de Joatão é praticamente o único texto que permite tal avaliação dupla e recíproca. ${ }^{15}$ Nela transparece um desprezo forte da monarquia por causa do seu efeito desumanizante, da sua fixação exclusiva no poder e, concomitantemente, a ordem "mais natural", que pode ser a dos clãs e tribos, fica idealizada. ${ }^{16}$

\section{Monarquia $=$ apostasia $\times$ tribalismo $=$ fé firme}

Aconteceu que depois da queda de Jerusalém, diante dos exércitos babilônicos, em 597 e 587 a.C., da extinção do reinado de Judá e das deportações de milhares de membros das elites da Judeia para a Babilônia, iniciava um pernicioso escrutínio teológico das causas dessa tragédia que profundamente marcou a espiritualidade do Antigo Israel dando ímpetos decisivos para a reorganização do povo de Javé, a criação de uma nova identidade, a assemblagem dos escritos sagrados, a instituição de

${ }^{13}$ A literatura preservada do antigo Oriente Médio inclui o gênero literário de "diálogo de contestação" entre coisas úteis para os seres humanos, cf. RÖMER, W. H. Ph. Die Sumerologie (AOAT 262). Münster: Ugarit-Verlag, 1999. p. 201,205-206. Faltam, até agora, discussões sobre a utilidade de diferentes formas da organização social.

${ }^{14}$ Algumas afirmações proféticas soam mais radicais: cf. Hos 8,10; 10,3; 11,5; Is 8,21; Jr 2,26, etc.; todas elas bem podem representar experiências exílicas.

${ }^{15}$ A idealização da vida nômade e tribal (cf. p.ex. Jer 35,1-11) visa à recusa da cultura sedentária, não precisamente da organização monárquica (veja em: baixo n. 5).

${ }^{16}$ Assim também CRÜSEMANN; WIDERSTAND, 1978. 
costumes e festas, resumindo: da nova comunidade judaica. Nesse contexto, a monarquia foi declarada a culpada número 1 , tendo todo o povo às vezes considerado como o número 2 na lista dos acusados. O fato interessantíssimo é que a denúncia dos monarcas de ambos os estados préexílicos quase ignora a função real, tão importante em épocas anteriores, quanto à mediação das graças divinas ao povo. Agora se justapõem simplesmente o próprio governo justo de Javé e a regência monárquica. Ou, para admitir um raciocínio mais adequado ao nosso pensar: talvez esses teólogos do período exílico e pós-exílico assumiam implicitamente que a classe real de Israel teria traído totalmente os seus ofícios divinos atestados em diversos lugares e que Javé queria, agora, assumir a regência do seu povo. ${ }^{17}$ Seja como for, precisamos olhar mais de perto essa teologia teocrática da época indicada.

$\mathrm{Na}$ nossa nomenclatura acadêmica usamos (por falta de nomes autênticos) a denominação "deuteronomista" para um grupo de transmissores e redatores responsáveis pela avaliação da história pecaminosa e o veredicto teológico sobre a instituição do reinado. ${ }^{18}$ Os livros "históricos" (Deuteronômio, Josué, Juízes, Samuel, Reis) foram compostos e/ou redigidos por eles, além de certos escritos proféticos (especialmente o do profeta Jeremias). Encontramos, nessas camadas da tradição israelita, uma boa porção de passagens bem críticas em relação aos reis do povo de Deus e, por outro lado, afirmações positivas quanto ao (futuro?) reinado de Javé sobre Israel. Todos esses posicionamentos levantam perguntas e dúvidas a respeito da sua intenção e direção. Será que Dt 17,14-20, por nós intitulada de "lei do reinado", teria sido a norma geral para os deuteronomistas quando eles refletiam o problema da organização justa de Israel, diante do seu Deus Javé, tendo em vista a catástrofe final de 587 a.C.? Essa ordenança básica prevê um rei totalmente desnudado de todos os instrumentos políticos normais (poder militar, harém, tesouro). Conforme os deuteronomistas ele deve, isso sim, estudar a Torá, quer dizer:

17 Já os cronistas do AT têm outra opinião sobre o assunto, cf. GERSTENBERGER, Israel 2005, p. 117-129; p. 216-234.

18 Essa designação fica contestada, cada vez mais, por exegetas que lamentam a insuficiência do seu valor interpretativo, cf. p.ex. LEUCHTER, M.; ADAM, K-P. (Ed.). Soundings in Kings. Perspectives and Methods in Contemporary Scholarship. Minneapolis: Fortress Press, 2010. Especialmente p. 1-11. 
ser um rabino exemplar que deriva as suas decisões diretamente da boca de Deus (Dt 17,18-20). Que é isso? Uma caricatura do rei? Os teólogos da época simplesmente projetam a sua própria imagem do rei Israelita "sentado no seu trono" (v. 18)? A convicção teológica por trás do rei piedosíssimo parece ser aquela já articulada em Jz 8,22-23, resumida nas seguintes palavras: "Deus mesmo é o nosso Senhor. Só ele vai nos governar".

Na sequência, nos livros dos Reis, os transmissores da tradição histórica realmente avaliam cada um dos regentes de Israel e Judá conforme a atuação deles no trono. Muitos recebem péssima avaliação: "fez o mal aos olhos de Javé" (24 vezes, cf. 1Rs 11,6; 14,22; 15,26.34; Davi: 1Rs 11,6; Asa: 1Rs 15,11.14, Josafá: 1Rs 22,43-44; Ezequias: 2Rs 18,3-7; Josias: 2Rs 22,3, todos fizeram “o que é reto [ou 'agradável'] aos olhos de Javé”, às vezes com pequenas reservas. Sem exceção são reis de Judá). Outro grupo recebe um claro veredicto por causa de "fazer o mal" (cf. 1Rs 16,30; 2Rs 21,2). O crime acusado é o de "servir a outras divindades" (por exemplo, 1Rs 12,31-33; 13,33-34; 14,22-24; 15,3.26.34; 16,13.25-26.30-33, etc.) bem de acordo com a pregação do livro do Deuteronômio. Esse medo de apostasia, de quebrar a aliança com Javé e assim perder a identidade genuína do corpo "eclesial" de Israel, é uma marca característica da época tardia do AT. A fidelidade ao Senhor Javé e o comportamento justo diante de Deus são a medida única que se aplica aos reis do passado.

A maioria dessas verificações éticas e teológicas a respeito dos reis, então, são julgamentos em retrospectiva, orientando-se nas normas espirituais daquele período exílico e pós-exílico no qual se formava a comunidade religiosa de Israel, ou seja, do judaísmo emergente. A Torá já era o cânon fixo da nova organização eclesial inédita no mundo antigo. Esse cânon previa uma alternativa simples a respeito do governo civil de Israel: a organização teoricamente poderia ser de cunho monárquico, o que na prática dos vencidos e subjugados desde o exílio não mais era uma opção realista. As tentativas de reestabelecer a dinastia de Davi provavelmente foram frustradas (cf. Ag 2,23). Existia somente uma opção razoável nessa comunidade de fé formada pelo povo e seus líderes atuais, a saber, as elites javistas deportadas (sacerdotes, levitas, escribas, anciãos) optaram pela regência exclusiva do próprio Javé, naturalmente mediada pelos "homens de Javé" intitulados para tal tarefa. Proclamando a teocracia pura - como 
sempre é o caso também em outras religiões e épocas culturais -, os líderes espirituais se instalavam como governantes chamados por Deus para executar a vontade divina. Nunca havia, na história global humana, um governo direto de Deus ordenando a vida diária das pessoas por uma voz celeste. De fato, Dt 5,23-31 explicitamente suprime tal modalidade teórica legitimando o sistema teocrático normal mediado pela classe espiritual. Diz o povo a Moisés nesse episódio-chave:

com efeito, quem dentre todos os seres carnais pôde, como nós, ouvir a voz de Deus vivo, falando do meio do fogo, e permanecer vivo? Aproximate para ouvir tudo o que Javé nosso Deus vai dizer. Tu nos dirás tudo o que Javé nosso Deus te falar. Nós ouviremos e colocaremos em prática" (Dt 5,26-27).

O pretexto para evitar um verdadeiro "governo direto" por parte de Javé justamente é a incapacidade do povo de aguentar a presença imediata divina. Assim, os escolhidos da divindade têm que sacrificar-se arriscando buscar e ouvir os mandamentos de Deus para comunicá-los e interpretá-los aos fiéis. Ou eles têm que operar o serviço sacrifical de expiação. É claro que até hoje tal tarefa perigosa de mediação entre divindade e humanidade constitui uma autoridade espiritual considerável e outros privilégios da classe religiosa governante.

Vemos que nesse quadro da rejeição do poder real não consta uma reflexão maior sobre outras estruturas sociais com outras formas de regência. A autoridade eclesiástica que implicitamente está sendo apresentada em alguns textos foge de uma discussão pública. Moisés pacificamente aceita o chamado do povo para mediar as palavras de Javé (Dt 5,28-31). Os sucessores do mediador superior sabiam defender a autoridade dele (e a sua própria também) com grande fervor (cf. Lv 10,1-5; Nm 12,1-9; 16). Consequentemente, na ausência de um debate teórico só podemos postular a estrutura eclesial por trás dos pensamentos teocráticos.

No livro de Jeremias, no entanto, encontramos um texto que talvez lance alguns sentimentos políticos distintos referentes a estruturas sociais fora da monarquia dinástica. Possivelmente, tais ideias também estavam no horizonte mental daqueles que rejeitavam a monarquia. O modelo exibido em Jr 35 é de uma família (clã?) de certo patriarca chamado Jonadab, 
o recabita. O grupo nômade precisou se refugiar diante do avanço dos babilônios em direção a Jerusalém. O profeta Jeremias, por ordem de Javé, prova a fidelidade deles diante das normas da vida não sedentária recebidas por Jonadab (não beber vinho, não construir casa, não semear, não plantar, não possuir terra e viver permanentemente em tendas: Jr 35, 6-7). Os membros do grupo são fiéis e, por isso, nomeados como grandes exemplos de boa fé:

(Oráculo de Javé): [....] Na verdade, os filhos de Jonadab, filho de Recab, observaram a ordem que lhes deu seu pai, mas o meu povo não me escutou! [...] Então Jeremias disse à casa dos recabitas: 'Assim disse Javé dos Exércitos Deus de Israel. Já que obedecestes à ordem de vosso pai Jonadab, observastes todas as suas ordens e pusestes em prática tudo o que vos ordenou, por isso, assim disse Javé dos Exércitos, Deus de Israel: Não faltará a Jonadab, filho de Recab, um descendente, que estará diante de mim todos os dias (Jr 35,16.18-19).

A visão idealizada da vida nômade em si não tem paralelo nas Escrituras. O trecho citado termina na clara preferência de Javé para um "descendente" de Jonadab (v. 19), anúncio do guerreiro zeloso javista batalhando com Jeú contra os reis maus (2Rs 10:15-17). Essa escolha de um chefe tribal e nômade contraria a tradição maior do AT. Já em Gn 4,11-13, a existência instável é vista como maldição. Os patriarcas itinerantes levam uma vida perigosa, cheia de faltas vivenciais (Gn 12-35; Dt 26,5-10). O ideal sempre era a posse de terra, a vida sedentária. Quanto à estrutura social da família, do clã ou da tribo, há poucos louvores fora dos perícopes mencionados. As estórias de Saul ainda deixam transparecer traços tribais: a liderança carismática, extática, cabe muito mais no contexto tribal do que em uma sociedade monárquica (cf. 1Sm 10,5-12; 11,5-11). Coleções de adágios antigos referentes às tribos (cf. Gn 49,2-28; Dt 33,2-29; Jz 5,13-18) são ecos muito distantes. Embora pressupondo um Israel já assentado, muitos episódios do livro dos Juízes ainda refletem memórias ou certas ideologias glorificando a vida antes dos reinados. Finalmente, alguns poucos Salmos tematizam os feitos da época inicial da história de Israel (cf. S1 78,67-72; 135).

Algumas observações quanto à posição teológica dos contos originais sobre "os juízes" ainda estão em ordem. Dificilmente os transmissores 
fazem reflexões comparativas em relação ao valor intrínseco dos sistemas tribal e dinástico. Existem dois focos nessas narrações sobre a época préestatal. Um tipo de texto descreve a atuação bélica, defensiva, de líderes carismáticos, como a de Débora ( $\mathrm{Jz} 4-5)$, Gideão ( $\mathrm{Jz} 7$ ) ou Jefté ( Jz 11) salvando o povo de Javé de opressores alheios (Sansão em Jz 13-16 já representa uma outra figura, a do nazireu, conforme Nm 6). ${ }^{19}$ Outro modelo de "governo" aparece em Jz 10,1-5; 12,8-15, em que alguns chefes tribais são nomeados como regentes de Israel. O termo hebraico špt, "julgar", "administrar", "governar", simplesmente quer indicar a função política desses homens. A maneira de descrever as pessoas (genealogia; tribo; tempo de governo; às vezes informações sobre o poder, as posses, a autoridade) tem semelhança com registros dos reis subsequentes. Mas faltam afirmações explícitas nessa tradição original, relativamente, a respeito da razão para esse fenômeno simples: as narrações sobre os "juízes" pré-estatais provêm de tradições locais, elevando heróis de porte limitado. Os autores iniciais, por sua vez, estavam longe de quaisquer especulações em torno de uma substituição da ordem tribal. Apenas o episódio de Abimelec, narrado em Jz 9 e entrelaçado com a fábula de Joatão, visa a essa possibilidade política. Por isso, o capítulo pode ser uma criação de avaliadores posteriores, que também eram responsáveis pela ligação dos contos individuais em sequência histórica e pelo julgamento final, de que o período dos Juízes significava desordem total e que a chegada da dinastia davídica significaria uma salvação divina. Em suma, as fontes mais antigas do livro dos Juízes nos deixam com um quadro histórico quebrado. Não existiam ainda instituições centrais em Israel; havia, isso sim, liderança e administração tribal descentralizadas, uma ou outra figura já transcendia os seus limites estreitos, chamando, por exemplo, outras tribos para uma guerra de Javé (cf. Jz 4-5) em um processo de unificação política emergente. E toda essa estrutura de base via de regra era sancionada ainda pelas divindades familiares e regionais (cf. Gn 31,43-54; $\mathrm{Jz}$ 12,1-6). ${ }^{20}$ Macro-organizações, como o "estado territorial”, estavam se

${ }^{19} \mathrm{Cf}$. Rüdiger Bartelmus, Heroentum in Israel und seiner Umwelt: eine traditionsgeschichtliche Untersuchung zu Gen. 6,1-4 und verwandten Texten im Alten Testament und der altorientalischen Literatur (ATANT 65), Zürich: Theologischer Verlag 1979.

${ }^{20}$ Cf. Gerstenberger, Teologias p. 36-115; p. 137-195. 
desenvolvendo gradativamente. Com isso, o debate em torno da necessidade de instalar um rei estava "diante das portas", mas não tinha ainda se infiltrado nos contos locais.

\section{Perspectivas da fé}

Fé e sociedade é um tema teologicamente muito importante no AT. É necessário, agora, somar os resultados deste artigo.

O AT preserva testemunhos da fé milenar israelita de vários níveis sociais e em circunstâncias históricas diferentes. Não é de estranhar, portanto, que variam consideravelmente as posições teológicas (implicando também afirmações políticas e éticas) ao longo da história Israelita com as suas transformações sociais claramente visíveis nos textos. Por essa razão encontramos nas Escrituras Hebraicas, em determinados instantes, fortes afirmações sobre a legitimidade de uma ou outra forma de liderança. Constata-se, também, uma consciência coletiva de que as mudanças sociais são causas efetivas para alterar estruturas herdadas do passado. Não há, pois, organização divina fixada eternamente no AT.

A convicção fundamental do antigo Oriente Médio, na verdade, favorece uma vida social organizada (sem falar ainda da ordem concreta) para toda a humanidade. Pessoas solitárias e isoladas são consideradas desprotegidas, miseráveis, amaldiçoadas, perdidas (cf. Gn 4,12-14; Lv 13,45-46; $1 \mathrm{Sm} 22,2)$. Os ideais da existência humana eram, por um lado, o grupo social pequeno interligado pela solidariedade absoluta de parentesco ou convivência (cf. 2Rs 4,13; Ecl 4,7-12) e, por outro lado, a organização social justa concordando com as concepções tradicionais de dignidade, liberdade, paz e bem-estar humano (Is 11,1-9; 61; Zc 8,4-17 etc.). Organização social, autoridade e poder de ordenar, de qualquer maneira, são imprescindíveis, mas cada forma de lidar ou governar deve ser medida com as normas de justiça. Há atuação legítima e ilegítima em todas as organizações possíveis e necessárias. A tentação de abusar do poder autoritário sempre fica presente. É certo que a benção de Deus só se realize com lideranças justas.

Se cada ordem social justa fica sob a supervisão divina, sejam os deuses ou deusas de cunho familiar, local, tribal, nacional ou paroquial, 
esperamos mais indicações do cuidado das divindades protetoras. Alguns livros proféticos, de fato, oferecem abundância de vindicações por causa de abuso de poder, normalmente nos níveis urbanos, nacionais, "eclesiais" (isto é, do pessoal religioso da época, cf. os livros de Amós, do primeiro Isaias, parte de Miquéias e Jeremias). Quase faltam acusações contra pais e chefes dos clãs. Isto significa que a literatura veterotestamentária, principalmente, se originou nos níveis secundários da sociedade. Transparecem, provavelmente, conflitos sociais em alguns ataques proféticos, simpatias com grupos marginalizados e explorados em determinadas conjunturas do tempo (cf. Am 2,6-8; 4,1; 5,11-15; 8,4-6; Isa 5,8-23; 10,1-2; Hab 2,620 , etc.), sempre mais se revelando uma crítica fundamental do poder humano. Ninguém deveria reinar sobre o "irmão" com dureza ( Lv 25,43; cf. Ex 21-23; Lv 19). Reclama-se o reino de Javé direto - com as consequências já elaboradas acima. Esse alvo teocrático de organização social deixa inferir uma sociedade religiosa como postulado antes para a época pós-exílica. Permanece o reconhecimento, no entanto, de que cada ordem justa de Deus para a humanidade deve ser debatida sempre de novo, acompanhando as mudanças da sociedade.

Um problema central, pelo menos da nossa visão moderna, é a relação entre gerência divina e a hierarquia social verdadeira. Podemos distinguir, dentro do AT, duas opções teóricas. A primeira admite que Deus reina por meio das autoridades humanas. Os pais, obviamente, atuando sob uma autorização divina merecem grande respeito e até reverência (cf. Ex 20,12; 21,15.17; Dt 27,16; Pr 1,8; 20,20; 30,11.17) e, igualmente, os líderes comunais ou nacionais (Ex 22,27; 1Sm 24,7; 2Sam 16,5-13; Sl 45, 3-9), pois eles servem como agentes fiéis de Deus revestidos de autoridade divina. Isso se vê em várias passagens escatológicas: um rei ungido ("messias") atua em plena conformidade com a vontade de Javé (cf. Isa 9,5-6; 11,1-9; Jr 33,14-16; Ez 34,23-24). O governo salvífico do futuro, nesse caso, funciona como uma monarquia. A segunda possibilidade é a atuação direta de Javé mesmo: "é Javé quem reinará sobre vós" ( $\mathrm{Jz}$ 8,23); "certamente eu mesmo cuidarei do meu rebanho e o procurarei" (Ez 34,11). As afirmações do reino direto e pessoal de Javé devem ser interpretadas, porém, como dissemos anteriormente, sob aspectos da teocracia mediada por teólogos. 
Cabe mencionar, mesmo de passagem, que muitas partes do AT evidenciam sentimentos fortes contra dominações estrangeiras: a saber, dos Filisteus, Midianitas, Egitos, Assírios, Babilônios, etc. (apenas o Império Persa escapa mais ou menos de todas as acusações, o rei Ciro recebe o título "messias", Is 44,28; 45,1; Esd 1,1-4). ${ }^{21}$ Muitas vezes, os reis estrangeiros servem como símbolos da opressão; na literatura profética, os guerreiros e exércitos estrangeiros frequentemente são mandados por Javé para castigar a infidelidade dos reis de Israel e Judá, bem como de todo o povo. Eles exercem uma administração tributária bastante dura e sem graça e assim talvez revelam, ao mesmo tempo, um traço essencial do sistema monárquico. O ponto mais interessante nesse contexto é o fato de que o governo de Salomão, em algumas passagens, fica denunciado com a mesma retórica antiescravizante como a atuação do faraó.

Finalmente, quero tocar dois problemas paradigmáticos de poder e autoridade sociais que estão bem atuais em nossos dias para refletirmos, também, sobre a ligação íntima entre antiguidade bíblica e desenvolvimentos atuais.

Se entendermos bem a linha de argumentação veterotestamentário a respeito da ordem social certa e justa, é possível constatar que nas fontes bíblicas existe um debate em torno do abuso de poderes e da melhor organização nos níveis nacional e eclesial. Essa visão dos conceitos políticos realistas daquela época ainda pode contribuir para a nossa ética social? A monarquia dinástica e divinizada dificilmente é uma opção teológica em nossa cultura de hoje. Se, no entanto, observarmos a longa luta do povo de Israel contra a escravidão e em prol da liberdade nacional, igualmente contra a arbitrariedade e em prol da justiça social para os pobres, podemos abraçar facilmente os desenvolvimentos modernos que se referem aos direitos individuais das pessoas - a sua dignidade e autonomia fundamentais - e incorporá-los (criticamente!) no nosso refletir teológico. Então, o diálogo necessário com os antepassados bíblicos se torna fértil, porque em muitas áreas da vida estamos ainda longe dos alvos humanitários (respeito ao outro; solidariedade global;

${ }^{21}$ Ironicamente, uma prece de Neemias contém a mais nítida descrição do enorme peso de uma exploração imperial externa (Ne 9,32-37: eles “dispõem a seu arbítrio de nossas pessoas e de nosso gado. Achamo-nos em grande aflição". v. 37).

Rev. Pistis Prax., Teol. Pastor., Curitiba, v. 3, n. 1, p. 77-98, jan./jun. 2011 
combate à fome, por saúde, educação, emprego, etc.). É verdade igualmente que o extremo subjetivismo da nossa época contradiz a valorização (demasiada?) da coesão coletiva em vários níveis da sociedade. Uma discussão contínua e profunda desses problemas fundamentais está em andamento.

Foi dito anteriormente que em uma convicção básica no antigo Oriente Médio, incluindo a Bíblia, está a das prerrogativas masculinas na vida pública. Qualquer tentativa de amenizar o quadro geral, apontando variações do machismo vigente na época, ou de indicar participações importantes de mulheres em ofícios normalmente reservados para homens não podem extinguir os padrões dominantes dos papéis genéricos nessa antiguidade predominantemente regida pelo sexo masculino. Como podemos nos liberar desse padrão antiquado de organização social? É verdade que em nossa época não mais pode valer uma estruturação da sociedade agrária, conforme a divisão do trabalho, em ocupações genéricas fixadas anteriormente: cabia à mulher providenciar e educar filhos e cuidar do lar e da horta, enquanto o homem tomava conta dos serviços exteriores (animais; proteção externa; assuntos públicos e judiciais). A nossa vida de longe mudou para os parâmetros urbanos, técnicos, científicos. Se não temos melhores razões humanitárias para advogar pela igualdade dos gêneros, é suficiente essa referência ao estado real da produção industrial, educação obrigatória e do processo democrático em nosso meio: não há chance nenhuma de negar direitos iguais às mulheres. As próprias condições de vida que a humanidade tem criado exigem uma ordem genérica igualitária. Podemos dizer, como já observado anteriormente, que como exegetas bíblicos responsáveis temos o dever sagrado de ativar os conceitos antigos, promover a igualdade dos gêneros e apreender ainda muito por meio do diálogo necessário com as testemunhas bíblicas. A libertação das mulheres e a cooperação mútua entre os dois gêneros são imprescindíveis em nosso mundo de hoje. As contribuições dos autores bíblicos, no entanto, oferecem as suas experiências antigas e certamente conhecem ainda facetas, para nós desconhecidas, do inter-relacionamento entre homens e mulheres. Dessa forma o círculo se fecha. Estamos, hoje em dia, tentando fixar novas regras para a humanidade. A democracia moderna continua sendo, por enquanto, um modelo adequado - mais ainda: melhor modelo possível para as nossas civilizações ocidentais e talvez para o mundo inteiro. 


\section{Referências}

ALBERTZ, R. Religionsgeschichte Israels (GAT 8/1/2). Göttingen: Vandenhoeck, 1992. v. 2.

CASALDÁLIGA, D. P. Cantigas menores. Goiânia: Projornal, 1979.

CRÜSEMANN, F. Widerstand gegen das Königtum (WMANT 49). NeukirchenVluyn: Neukirchener Verlag, 1978.

Gerstenberger, E. S. Theologien im Alten Testament. Pluralität und Synkretismus alttestamentlichen Gottesglaubens. Stuttgart: Kohlhammer, 2001.

GERSTENBERGER, E. S. Biblische Enzyklopädie: Israel in der Perserzeit. Stuttgart: Kohlhammer, 2005. 5. und 4. Jahrhundert v. Chr: Bd. 8.

GOTTWALD, N. The tribes of Yahweh: a sociology of the religion of liberated Israel, 1250-1050 BCE. Maryknoll: Orbis Books, 1971.

KESSLER, R. Sozialgeschichte des alten Israel: eine einführung. Darmstadt: Wissenschaftliche Buchgesellschaft, 2006.

MYERS, C. Discovering Eve. Oxford: University Press, 1988.

MÜLLER, R. Königtum und Gottesherrschaft: Untersuchungen zur alttestamentlichen Monarchiekritik (FAT II, 3). Tübingen: Mohr, 2004.

RIBEIRO, D. 0 processo civilizatório: estudos de antropologia da civilização. 5. ed. Petrópolis: Vozes, 1979.

Recebido: 13/03/2010

Received: 03/13/2010

Aprovado: 24/06/2010

Approved: 06/24/2010 